\title{
Development of a HPLC-DAD Method for the Simultaneous Quantification of 5-O- $\beta$-D-galactopyranosyl-7-methoxy-3',4'-dihydroxy-4-phenylcoumarin and its Aglycone in Feces
}

\author{
Cristians Sol, ${ }^{1,2}$ Rubio-Carrasco Kenneth, ${ }^{3}$ Díaz-Juárez Angélica Soledad, ${ }^{3}$ González-Covarrubias Vannesa ${ }^{4}$ \\ and Fuentes-Noriega Inés ${ }^{3 *}$ \\ 1 Laboratorio de Etnobotánica, Jardín Botánico, Instituto de Biología, Universidad Nacional Autónoma de México, México D.F., 04510. \\ 2 Laboratorio 124, Departamento de Farmacia, Facultad de Química, Universidad Nacional Autónoma de México, México D.F., 04510. \\ 3 Laboratorio 113, Departamento de Farmacia, Facultad de Química, Universidad Nacional Autónoma de México, \\ México D.F., 04510. \\ ${ }^{4}$ Laboratorio de Famacogenética, Instituto Nacional de Medicina Genómica, México D.F., 14610. \\ * Fuentes-Noriega I, Laboratorio 113, Departamento de Farmacia, Facultad de Química, Universidad Nacional Autónoma \\ de México, México D.F., 04510. \\ E-mail: ifuentes@unam.mx
}

Received March 11 ${ }^{\text {th }}, 2016$; Accepted June $17^{\text {th }}, 2016$.

\begin{abstract}
A sensitive and specific HPLC-DAD method was developed and validated for the simultaneous quantification of $5-O-\beta$-D-galactopyranosyl-7-methoxy-3',4'-dihydroxy-4-phenylcoumarin (4-PC) and its aglycone in rat feces. The 4-phenylcoumarins are important antidiabetic and gastroprotective bioactive metabolites of a highly commercialized medicinal plant complex in Mexico, the Copalchi complex. Both the sample preparation and the quantification method were developed; the methodology allows, for the first time ever, the simultaneous determination of the 4-PC $\left(\mathrm{R}_{\mathrm{t}}=2.4 \mathrm{~min}\right)$ and its metabolized aglycone $\left(\mathrm{R}_{\mathrm{t}}=7.5 \mathrm{~min}\right)$, aimed to their pharmacokinetic analysis, specially their elimination. Linearity was determined in the range, $0.09-4.5 \mu \mathrm{g} / \mathrm{mL}$ for both compounds $\left(\mathrm{R}^{2}=0.9999\right)$. Accuracy was $<15.0 \%$ for 4 -PC and aglycone with an inter-assay precision of maximum $\%$ RSD of $6.1 \%$ for 4 -PC and $2.7 \%$ for the aglycone. The intra-assay precision was $\% \mathrm{RSD}<7.5$ for 4 -PC and $<3.5 \%$ for the aglycone. Analyte recovery from spiked samples was always $>98.02 \%$ for 4-PC and $>96.61 \%$ for its aglycone. The method was successfully applied to a single-dose preclinical pharmacokinetics preliminary study in rats.
\end{abstract}

Key words: 4-phenylcoumarin; aglycone; Copalchi; HPLC-DAD; pharmacokinetic.

$\begin{array}{ll}\text { Abbreviations } \\ \text { 4-PC } & \begin{array}{l}\text { 5-O- } \beta \text {-D-galactopyranosyl-7-methoxy-3',4'- } \\ \text { dihydroxy-4-phenylcoumarin }\end{array} \\ \text { DAD } & \begin{array}{l}\text { Diode array detector } \\ \text { HPLC }\end{array} \\ \text { High performance liquid chromatography } \\ \text { LLOQ } & \text { Lower limit of quantification } \\ \text { RSD } & \text { Relative standard deviation } \\ \text { TFA } & \text { Trifluoroacetic acid }\end{array}$

Resumen. Se desarrolló y validó un método analítico en HPLC-DAD sensible y específico para la cuantificación simultánea de la 5-O-B-D-galactopiranosil-7-metoxi-3',4'-dihidroxi-4-fenilcumarina (4-FC) y su aglicona en heces de rata. Las 4-fenilcumarinas son importantes metabolitos bioactivos antidiabéticos y gastroprotectores presentes en un complejo de plantas altamente comercializado en México: el complejo Copalchi. Se generaron los parámetros para la preparación de la muestra y su análisis; el método desarrollado permite, por vez primera, la cuantificación simultánea de la 4-FC $\left(\mathrm{t}_{\mathrm{r}}=2.4 \mathrm{~min}\right)$ y su metabolito, aglicona $\left(t_{r}=7.5 \mathrm{~min}\right)$, enfocado al análisis farmacocinético, especialmente su eliminación. La linealidad fue determinada en el rango de $0.09-4.5 \mu \mathrm{g} / \mathrm{mL}$ para ambos compuestos $\left(\mathrm{R}^{2}=0.9999\right)$. $\mathrm{La}$ exactitud fue $<15.0 \%$ para $4-\mathrm{FC}$ y su aglicona con una precisión inter-ensayo de máximo $\%$ RSD de $6.1 \%$ para 4 -FC y $2.7 \%$ para la aglicona. La precisión intraensayo fue $\% \mathrm{RSD}<7.5$ para 4 -FC y $<3.5 \%$ para la aglicona. El recobro de los analitos a partir de muestras enriquecidas fue siempre $>98.02 \%$ para $4-\mathrm{FC} \mathrm{y}>96.61 \%$ para la aglicona. La metodología analítica fue utilizada de manera exitosa en un estudio preliminar farmacocinético preclínico de una sola dosis en ratas.

Palabras clave: 4-fenilcumarina; aglicona; Copalchi; HPLC-DAD; farmacocinética.

\section{Introduction}

The extremely bitter stem-bark of some Mexican Rubiaceae species, commonly known as "Copalchi" has been used in Mexican traditional medicine for over 400 years with well-documented ethnomedical properties; Hintonia species are widely commercialized under the names, copalchi, copalquín, cáscara sagrada and quina [1-9]

The chemical composition has been documented in detail $[8,10-14]$ together with these therapeutic properties as antidiabetic [15-21], gastroprotective [9], antimalarial [14, 22] and antimicrobial [23] mostly of the stem-bark of H. latiflora. More 
recently, the antidiabetic, antinociceptive and gastroprotective properties have been described along with several specific chemical constituents of $H$. standleyana stem bark $[9,24,25]$.

Phytochemical analyses of the stem bark of Hintonia species have allowed the discovery of several new 4-phenylcoumarin glycosides and the identification of cucurbitacins, a novel styrene, and desoxycordifolinic acid an indole alkaloid [8]. The cucurbitacins are based on dihydrocucurbitacin F; whereas the 4- phenylcoumarins described were 5,7,3', $4^{\prime}$ '- or 5,7,4' - substituted with oxygenated functionalities, with the former having the most common pattern; the sugar portion is usually a monosaccharide ( $\beta$-D-galactose, $\beta$-D-glucose, $6{ }^{\prime \prime}$-acetyl- $\beta$-D-glucose, or 6 "-acetyl- $\beta$-D-galactose), although a few disaccharides were also found $(\beta$-D-apiofuranosyl- $(1 \rightarrow 6)-\beta$-D-glucopyranose or $\beta$-D-xylopyranosyl-( $(1 \rightarrow 6)-\beta$-D-glucopyranose). In all cases, the saccharide unit is attached to the hydroxy group at C-5. In acid conditions, the 4-phenylcoumarin glycosides undergo hydrolysis, generating its respective aglycone. Also, it was demonstrated that 4-phenylcoumarins undergo oxidative cyclization under aerobic alkaline conditions to give oxido-4-phenylcoumarins. Thus, if oxidocoumarins are natural products, they might be generated from simple 4-phenylcoumarins via an oxidative phenol coupling reaction [8].

Different "Copalchi" are mostly for the treatment of type-2 diabetes [8]. Diabetes currently represents a world-wide epidemic and Mexico shows one of the highest incidences of these diseases. According to the National Health Survey ENSANUT-2012 there are 6.4 million adults diagnosed with type-2 diabetes and it is the first cause of death among urban Mexicans [26], thus there might be a potential increase in the use and consumption of copalchi preparations. Mexican herbal medicine, "herbolaria", has a wide and long tradition in our country hence, it is imperative to establish methods for safety and efficacy of these preparations, in order to avoid marketing of low quality herbal products and decrease the risk of side effects and drug interactions among the consumer population.

To establish efficacy and safety of a drug it is necessary to assess the various pharmacokinetic parameters such as plasmatic concentration (Cp), area under curve (AUC), and half life $\left(t^{1} / 2\right)$ of the major component/drug after administration. It is part of the preclinical studies to develop methods to quantitatively determine the compound(s) of interests in different matrices including biological fluids. Usually, there is a lack of analytical methods aimed to the pharmacokinetic studies related with the Mexican traditional medicine; thus, the development and validation of analytical methods for this purpose is required.

Several methods for the quantification of natural products were developed, mainly aimed to quality control of herbal drugs. The situation of 4-phenylcoumarins is no exception, the analytical methods generated were fixed on quantify these compounds as active markers of the stem-bark infusions of $H$. latiflora and $H$. standleyana crude drugs, using HPLC-UV detector [27], identify the 4-phenylcoumarins as chemical constituents of the leaves infusions of both Hintonia species by HPLC method [28]. Recently, the simultaneous quantification of both 4-phenylcoumarins and chlorogenic acid in Exostema caribaeum stem-bark aqueous extract by UPLC-PDA method has also been reported [29]; nevertheless, there is no records of analytical methods aimed to detect and quantify the 4-phenylcoumarins and their metabolites, the aglycones, in biological matrices as a part of pharmacokinetics studies. The goal of this investigation was to develop and validate an HPLC-DAD method for the quantification of 4-phenylcoumarin and its aglycone in biological fluids, such as feces in order to apply it in preclinical pharmacokinetic studies.

\section{Materials and methods}

\section{Chemicals and solutions}

The Dr. Rachel Mata's pharmacognosy research group from the Faculty of Chemistry, UNAM, provided the $5-O-\beta-\mathrm{D}-\mathrm{ga}-$ lactopyranosil-7-methoxy-3',4'-dihidroxy-4-phenylcoumarin (4-PC; Fig. 1A) and its aglycone, 7-methoxy-5,3',4'-trihydroxy-4-phenylcoumarin (Fig. 1B). Analytical standard 4-PC was isolated from the stem-bark of Hintonia species as previously described by Guerrero-Analco et al. [17, 27]; its aglycone was obtained by acid hydrolysis of compound 4-PC ( $2 \mathrm{M} \mathrm{HCl}$ was heated until reflux began, this being held for 2 hours) [27]. The purity of both compounds was measured by HPLC-DAD at $325-330 \mathrm{~nm}$, being the analyte signal always above $90 \%$ of total peak area. Organic solvents were HPLC grade and were purchased from Tecnolab (Mexico), trifluoroacetic acid (TFA) from Sigma-Aldrich (Mexico), deionized water was obtained from a Milli-Q system (Millipore, Milford, MA, USA). The samples were lyophilized (LABCONCO, Kansas City, MO, USA).

A mixed stock solution containing both analytes at $1.5 \mathrm{mg} / \mathrm{mL}$ was prepared by dissolving each compound in acidified water $(0.1 \% \mathrm{TFA})$ and acetonitrile $(24: 76 \mathrm{Vol} / \mathrm{Vol})$. Working solutions were prepared by diluting the stock solution with mobile phase, covering the concentration range of 22.5 to $1125 \mu \mathrm{g} / \mathrm{mL}$.

\section{Calibration curve and quality control points in feces}

Spiked lyophilized fecal samples pool with $200 \mu \mathrm{L}$ of working solutions (50 $\mathrm{mg}$ aliquots) used as calibration standards were prepared, on a daily basis, at concentration of $0.09,0.45,0.90$,
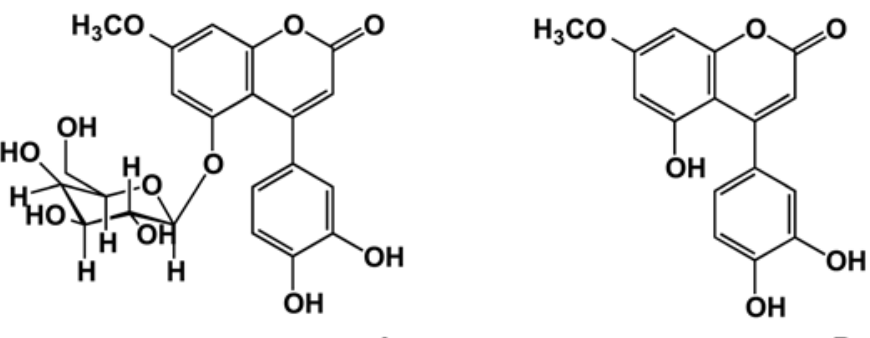

A

Fig. 1. A. 5-O- $\beta$-D-galactopyranosil-7-methoxy-3',4'-dihidroxy-4phenylcoumarin (4-PC). B. Structure of 4-PC aglycone, 7-methoxy-5,3',4'-trihydroxy-4-phenylcoumarin. 
$2.25,4.5 \mu \mathrm{g} / \mathrm{mg}$ of 4-PC and aglycone. Fecal quality control and stability samples were prepared at $0.3,1.5$ and $3.0 \mu \mathrm{g} / \mathrm{mg}$ of 4-PC and aglycone in freezed-dried feces, both samples were stored in plastic tubes at $-20^{\circ} \mathrm{C}$ until analyzed. All quality control samples were analyzed in replicate $(\mathrm{n}=5)$ on each of three analysis days. Next, analytes were extracted from this matrix.

\section{Animals}

Six male Wistar rats, weighting 200-250 g were purchased from Harlan (Mexico) and maintained under controlled conditions in metabolic cages and they had free access to water and food, a regular $12 \mathrm{~h}$ light/darkness was established at a room temperature $\left(22^{\circ} \mathrm{C}-24^{\circ} \mathrm{C}\right)$ and $45 \%$ of relative humidity. At the time of sampling, animals were fasted for $12 \mathrm{~h}$. The study was performed under institutional animal experimental guides, and protocols were reviewed and approved by the committee for Laboratory Animal Care (CICUAL) of the Faculty of Chemistry, UNAM.

\section{Feces sampling and analyte extraction}

Treated rats received a single dose of $90 \mathrm{mg} / \mathrm{kg}$ body weight $(n=6)$ of 4-PC dissolved in saline solution by oral gavage. Control rats received orally saline solution. Feces were collected from their metabolic cages at $0,12,18,24,36,48,60$, and $72 \mathrm{~h}$. Feces samples were weighed and lyophilized, 4-PC and its aglycone were extracted from $50 \mathrm{mg}$ of lyophilized feces with $200 \mu \mathrm{L}$ of extraction solution (TFA acidified water $0.1 \%$ : acetonitrile 76:24 Vol/Vol), homogenized for 10 minutes in a Heidolph MultiReax Heidolph (Instruments GmbH \& Co.KG Walpersdorfer, Germany) and added with $1300 \mu \mathrm{L}$ of extraction solution again, samples were vortexed for $15 \mathrm{~min}$ and centrifuged for $10 \mathrm{~min}$ at $10,000 \mathrm{rpm}$, supernatant was placed in a tube and centrifuged for another $10 \mathrm{~min}$ at $10,000 \mathrm{rpm}$.

\section{Method validation}

The method was validated according to the US Food and Drug Administration guidelines on bionalytical method validation [30], the Mexican Official Norm (NOM-177-SSA1-2013) [31], the quantitative bioanalytical methods validation and implementation [32], and the harmonized tripartite guideline [33]. The validation parameters included in the method were the following: linear regression model, accuracy, precision, selectivity, recovery, and stability.

\section{Chromatographic analysis}

Since the previous analytical methods for quantification of 4-phenylcoumarins [27-29] did not work in a biological matrix base analysis, different mobile phases (acetonitrile and TFA acidified water 50:50 Vol/Vol; 20:80 Vol/Vol; 24:76 Vol/Vol; 15:85 Vol/Vol; 10:90 Vol/Vol), flow rates $(1 \mathrm{~mL} / \mathrm{min} ; 1.2 \mathrm{~mL} / \mathrm{min}$; $1.5 \mathrm{~mL} / \mathrm{min}$ ), columns (Symmetry C-18, Waters; Synergi C-18,
Phenomenex; Eclipse C-8, Agilent; Zorbax C-18, Agilent) and column temperature were tested in order to obtain chromatographic resolution. The detection wavelength was set at 328nm in an HPLC-DAD 1100 (Agilent Technologies, Palo alto, CA, USA).

\section{Results and discussion}

\section{Chromatographic analysis}

The method development and optimization were established empirically for the best solubilization conditions for both 4-PC and aglycone; also, the former analytical methods reported for 4-phenylcoumarins analysis [27-29] were considered for those goals (Table 1). The development of this method was focused to the column, mobile phase and flow rate, in order to achieve the simultaneous detection and quantification of the bioactive compounds in feces in the less analytical time.

Different columns were used: Symmetry C-18 (4.6 X 150 mm, $5 \mu \mathrm{m}$ particle size), Synergi C-18 (4.6 X $150 \mathrm{~mm}, 4 \mu \mathrm{m}$ particle size), Zorbax C-18 (4.6 X $150 \mathrm{~mm}, 3.5 \mu \mathrm{m}$ particle size) and Eclipse C-8 (4.6 X $150 \mathrm{~mm}, 5 \mu \mathrm{m}$ particle size). Except for the latter column, all of them were $\mathrm{C}-18$ showing low-resolution analytes peaks, with wide bases interfering with the integration; the Eclipse C-8 column show a highly performances with well-defined peaks (Fig. 2).

The mobile phase was also based in the reported analytical methods: acetonitrile and $0.1 \%$ TFA acidified water; nevertheless, the solubility of the aglycone increased in non-polar organic solvents, for this reason different proportion was assayed: 50:50 Vol/Vol; 20:80 Vol/Vol; 24:76 Vol/Vol; 15:85 Vol/Vol; and 10:90 $\mathrm{Vol} / \mathrm{Vol}$. The increase in solubility does not signify a better chromatogram; indeed, it was the opposite, the use of non-polar mobile phase $(50: 50 \mathrm{Vol} / \mathrm{Vol})$ retains the compounds, giving analytical times around 45 minutes. The opposite proportion $(10: 90 \mathrm{Vol} / \mathrm{Vol})$ produces a chromatogram without definition, merging both analytes; also the 15:85 Vol/Vol proportion, merges the 4-PC with the characteristic peaks of the feces blank sample.

The flow rate was tested in order to optimize the distance between the 4-PC and its aglycone and the total analysis time. $1.0 \mathrm{~mL} / \mathrm{min}, 1.2 \mathrm{~mL} / \mathrm{min}$ and $1.5 \mathrm{~mL} / \mathrm{min}$ were tested, being the lowest flow rate inappropriate because of the total analysis time over 20 minutes; the use of a highest flow generates a poor separation between the analytes, merging the peak bases.

Suitable HPLC-DAD separation conditions were achieved with an Eclipse XDB-C8 (4.6 x $150 \mathrm{~mm}, 5 \mu \mathrm{m}$ particle size) column attached to an Eclipse XDB-C8 (4.6 x $12.5 \mathrm{~mm}, 5 \mu \mathrm{m}$ particle size) pre-column, at $25^{\circ} \mathrm{C}$ controlled temperature. The mobile phase was TFA acidified water $0.1 \%$ - acetonitrile $76: 24 \mathrm{Vol} / \mathrm{Vol}$, at $1.2 \mathrm{~mL} / \mathrm{min}$ flow rate, since it offered six-fold better signal-to-noise ratio compared to other mobile phases tested, and improved resolution between analytes, from 4.0 to 11.0. The injection volume in all cases was $20 \mu \mathrm{L}$. 
Table 1. Comparative chart between the published analytical methodologies for 4-phenylcoumarins.

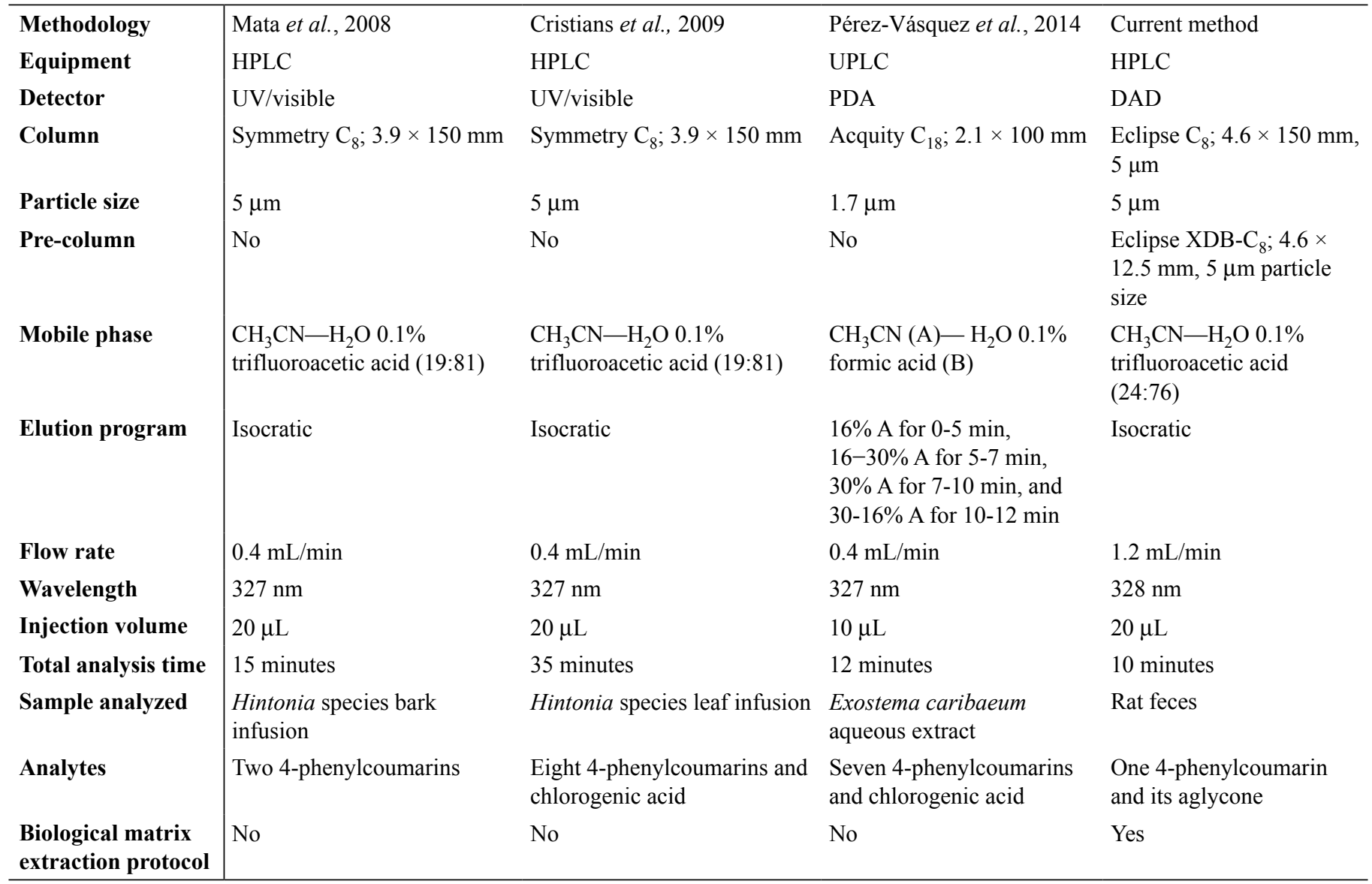

\section{Sample preparation}

Several extraction conditions were tested; different solutions based in the mobile phase, varying volumes, homogenization times, and sample filters were tested until we reached an overall mean recovery of $101.4 \%$ for $4-\mathrm{PC}$ and $100.8 \%$ for its aglycone with a $200 \mu \mathrm{L}$ of TFA acidified water $0.1 \%$ : acetonitrile $76: 24$ $\mathrm{Vol} / \mathrm{Vol}$ and homogenization for $10 \mathrm{~min}$; filtration process was not necessary due to absence analytical improvement. During the different conditions tested, the accurate signal and resolution of the analytes peaks were the features taken into account for the design of the final sample preparation protocol.

\section{Method validation}

Calibration curves were constructed by plotting the peak areas (y) against the corresponding standard concentration $(x, \mathrm{mg} / \mathrm{mL})$ using a linear least square fit regression model. The calibration curves showed good linearity within the tested concentration ranges: $0.09-4.5 \mu \mathrm{g} / \mathrm{mg}$ for both 4-PC and aglycone. Determination coefficients of $\mathrm{r}^{2} \geq 0.999$ were obtained for both analytes. The linear least square fit regression equations calculated for 4PC were $y=527.63 x+5.8$, whereas for aglycone were. $y=615.66 x-8.16$. The calibration curve obtained was tested by means of an ANOVA $(p=0.05)$, with confidence intervals between $-5.17-16.77$, and a slope limits between 522.85-532.41 for 4-PC, and confidence intervals between -25.18-8.85, and a slope limits between 608.24-623.07 for aglycone.

The regression model was evaluated by comparing the obtained mean values and those of the back-calculated concentrations of the calibration standards: these values should be within $\pm 15 \%$ RSD of the actual concentration, except for the lower limit of quantification (LLOQ) which is allowed an RSD within $\pm 20 \%$ of the actual concentration [30]. Values obtained were $<1.7 \%$ for the calibration curve and $<6.7 \%$ for the LLOQ. Deviations of measured from nominal concentrations were between $-10.0-5.8 \%$ and $5.3-6.1 \%$ with RSD values of $<6.9 \%$ and $<12.2 \%$ for $4-\mathrm{PC}$ and its aglycone. Typical chromatograms of the analytes in solution, blank samples, spiked blanks and biological samples from feces are depicted in Fig. 2.

The method accuracy and precision were investigated at three different concentration levels with five replicates per level (control concentration levels: $0.3 \mu \mathrm{g} / \mathrm{mg}, 1.5 \mu \mathrm{g} / \mathrm{mg}$ and $3 \mu \mathrm{g} / \mathrm{mg}$ in feces). The accuracy was defined as the percentage difference between the measured and the nominal concentration. Accuracy and precision of intra and inter-assays presented a RSD $<20 \%$ (LLOQ $=0.09 \mu \mathrm{g} / \mathrm{mg}$ ), and for the analytes linear range $(0.09-4.5 \mu \mathrm{g} / \mathrm{mg})$ accuracy was $<15.0 \%$ for $4-\mathrm{PC}$ and aglycone with an inter-assay precision of maximum \%RSD 


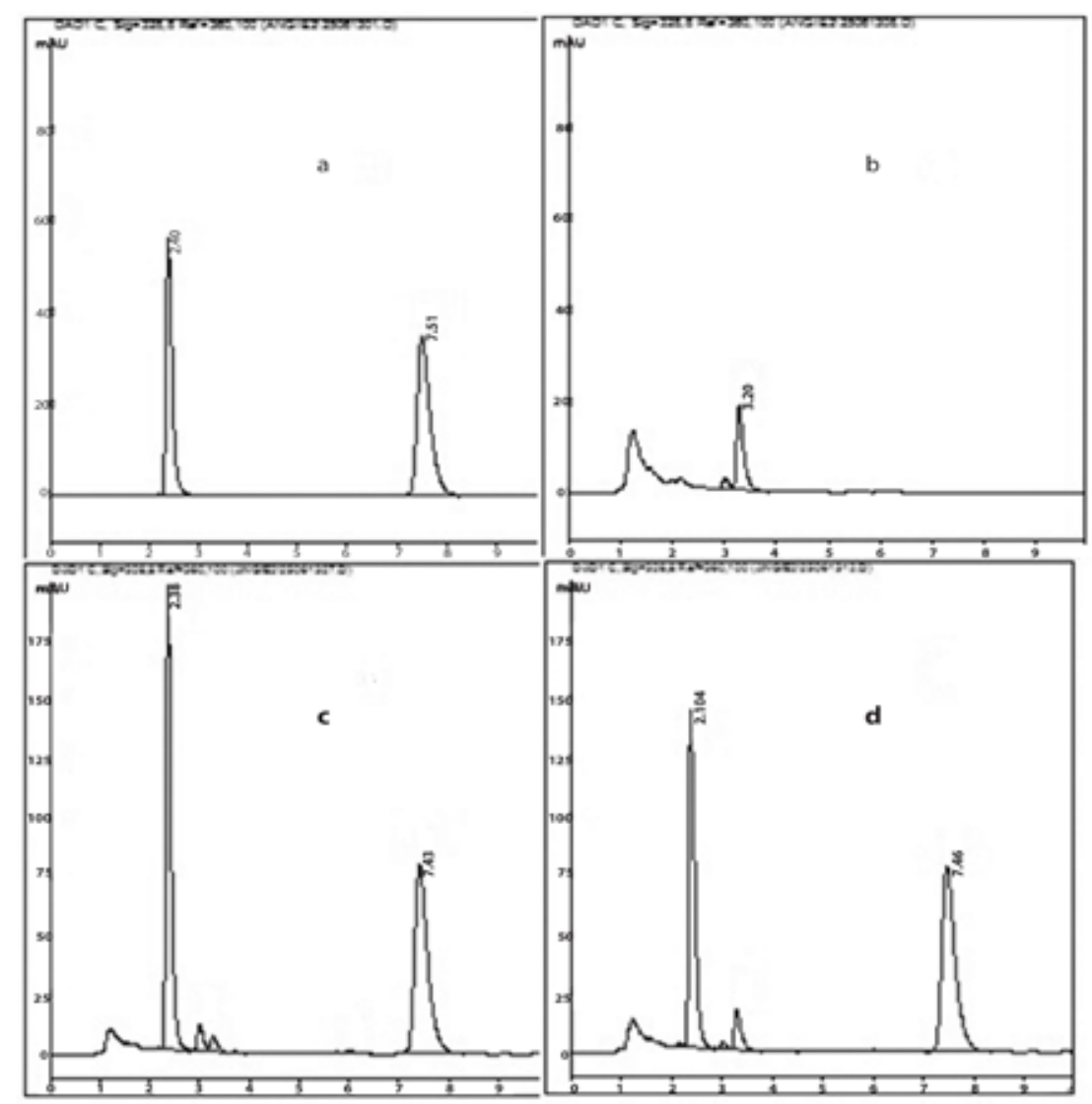

Fig. 2. Typical chromatograms of analytes in solution and matrix. (a) Representative chromatogram of a stock solution (b) blank feces sample, (c) Mid-level of the standard curve in feces $(75 \mathrm{mcg} / \mathrm{mL})$, (d) Feces sample collected 12 to 18 hours after administration of a $90 \mathrm{mg} / \mathrm{kg}$ dose.

of $6.1 \%$ for $4-\mathrm{PC}$ and $2.7 \%$ for the aglycone (Table 3 ). The intra-assay precision was $\% \mathrm{RSD}<7.5$ for 4 -PC and $<3.5 \%$ for the aglycone. A summary of the validation parameters are presented in Table 2 and 3, both analytes and all parameters fulfilled the validation-required criteria by the US Food and Drug Administration and the NOM-177-SSA1-2013 [30-31].

Selectivity was evaluated to in order to demonstrate the lack of interferences from endogenous compounds in the chromatographic analysis. Six pooled batches of control feces were used to prepare blanks and spiked samples with 4-PC and its aglycone at the LLOQ concentration level. The analytes eluted at 2.4 and 7.5 minutes respectively. Retention time and area under the curve of potential interfering endogenous compounds were $<5.2 \%$ from 4 -PC and $<2.2 \%$ for its aglycone, lower than the reported nominal limit allowed of $<20 \%$.

Recovery after extraction was determined by comparing the absolute peak areas after extraction of the analytes in solution at three concentration levels. Recovery was $98.02 \%$ $(\% \mathrm{RSD}=3.89)$ for $4-\mathrm{PC}$ and $96.61 \%(\% \mathrm{RSD}=3.08)$ for its aglycone, showing a consistent and efficient extraction.

Stability was also assessed at three concentrations levels for stock solutions after storage at room temperature for $48 \mathrm{~h}$ and refrigeration $\left(2-8^{\circ} \mathrm{C}\right)$ during 5 days. Stock solutions were stable under these conditions, extraction showed a variation of $<1.8$ RSD for $4-\mathrm{PC}$ and $<1.2 \%$ RSD for the aglycone. Stability was also assessed for the sample in the biological matrix at $-20^{\circ} \mathrm{C}$ and for two freeze-thaw cycles with at least 30 days in between.

\section{Preclinical pharmacokinetic study}

The validated method was used to measure 4-PC and its aglycone in a preliminary preclinical pharmacokinetic study. Briefly, rats received $90 \mathrm{mg} / \mathrm{kg}$ bw of 4-PC by oral gavage; feces were collected after $72 \mathrm{~h}$. Fig. $3 \mathrm{~A}$ and $3 \mathrm{~B}$ shows fecal excretion of 4-PC and its aglycone. We determined that $17.17 \mathrm{mg}$ $(88 \%)$ of the total orally administered dose of colpalchi is eliminated in feces as $13.68 \mathrm{mg}$ of 4-PC (70.1\%) and $3.49 \mathrm{mg}$ of its aglycone (18.1\%). This study represents the basis for future preclinical analyses determining the elimination ratio of the bioactive compounds.

\section{Conclusions}

We developed and validated an analytical method to quantify 4-PC and its aglycone in rat feces. Whereas the methods reported previously were dedicated to quality control tests of crude drugs, the procedure proposed here is aimed to the biopharmaceutical analysis, using a simple and available HPLC-DAD 
Table 2. Validated parameters for 5-O- $\beta$-D-galactopyranosyl-7-methoxy-3',4'-dihydroxy-4-phenylcoumarin (4-PC) and aglycone in rat feces.

\begin{tabular}{|c|c|c|}
\hline Parameter & 4-PC & Aglycone \\
\hline Calibration Range $(\mu \mathrm{g} / \mathrm{mg})$ & $0.09-4.5$ & $0.09-4.5$ \\
\hline Calibration Curve Equation & $y=527.63 x+5.8$ & $y=615.66 x-8.16$ \\
\hline Confidence interval & $-5.17-16.77$ & $-25.18-8.85$ \\
\hline Signal to noise ratio (LLOQ) & $\geq 5$ & $\geq 5$ \\
\hline Accuracy $(\% \mathrm{RSD})^{\S}$ & $8.58 \%$ & $6.10 \%$ \\
\hline Selectivity & $\leq 5.2 \%$ & $\leq 2.2 \%$ \\
\hline Stability in matrix at room temperature, $24 \mathrm{~h}$ & $\begin{array}{c}\text { Accuracy } \\
98.36 \% \\
\% \text { RSD }=6.88\end{array}$ & $\begin{array}{c}\text { Accuracy } \\
96.51 \% \\
\% \text { RSD }=6.29\end{array}$ \\
\hline Stability in matrix at $2-8^{\circ} \mathrm{C}, 24 \mathrm{~h}$ & $\begin{array}{c}\text { Accuracy } \\
98.54 \% \\
\% \text { RSD }=4.6\end{array}$ & $\begin{array}{c}\text { Accuracy } \\
95.75 \% \\
\% \text { RSD }=7.15\end{array}$ \\
\hline Stability of stock solution at room temperature, $48 \mathrm{~h}$ & $\begin{array}{c}\text { Accuracy } \\
99.14 \% \\
\% \text { RSD }=5.81\end{array}$ & $\begin{array}{c}\text { Accuracy } \\
94.58 \% \\
\% \text { RSD }=4.39\end{array}$ \\
\hline
\end{tabular}

$\S$ Control concentration levels: $0.3 \mu \mathrm{g} / \mathrm{mg}, 1.5 \mu \mathrm{g} / \mathrm{mg}$ and $3 \mu \mathrm{g} / \mathrm{mg}$.

Table 3. Intra- $(n=5)$ and inter-assay $(n=15)$ precision data for quality control samples.

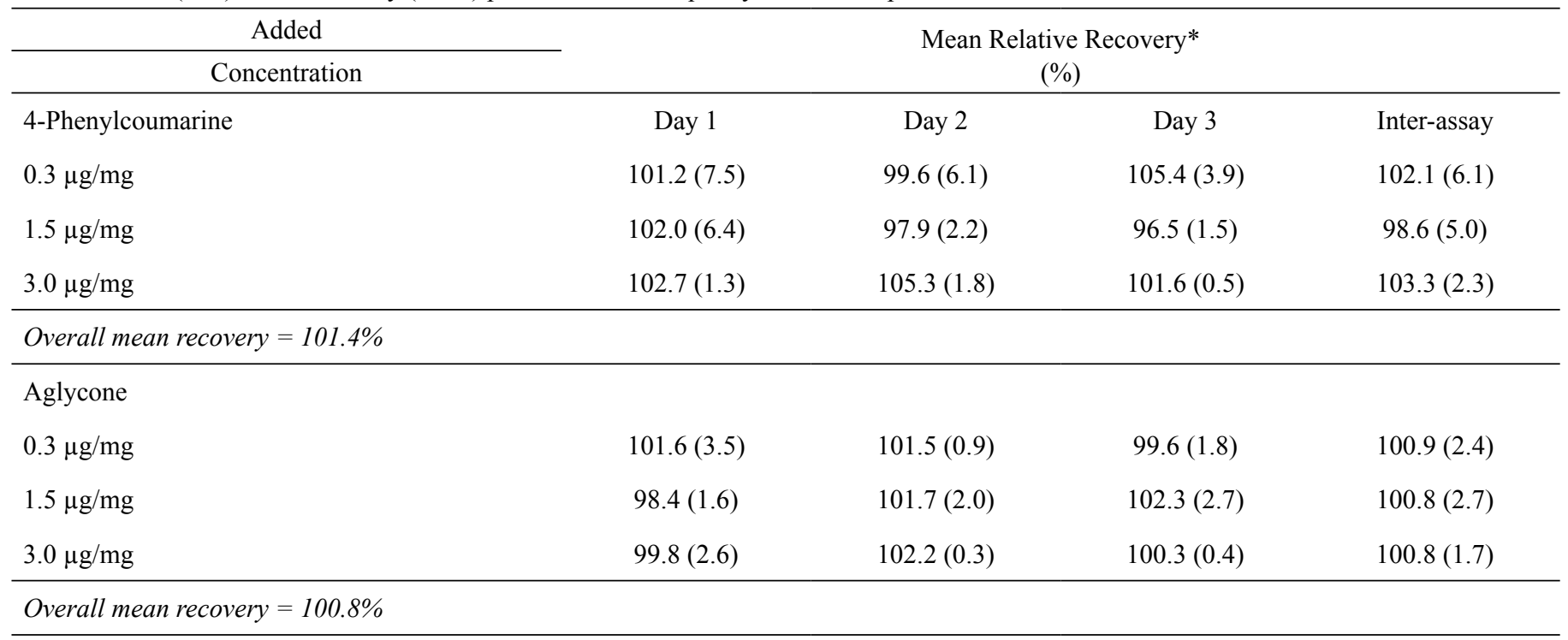

* Values in parentheses are coefficients of variation (\%) 
$\mathbf{A}$

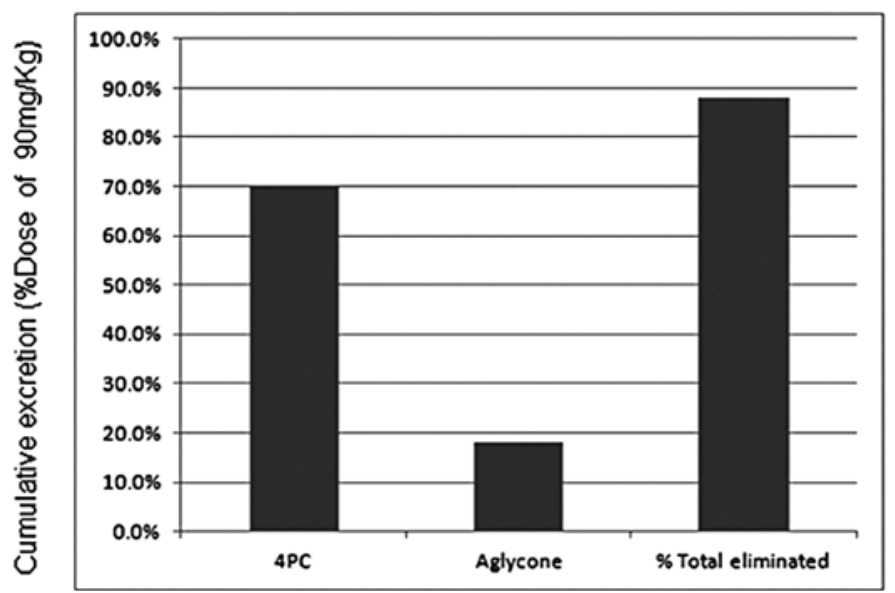

B

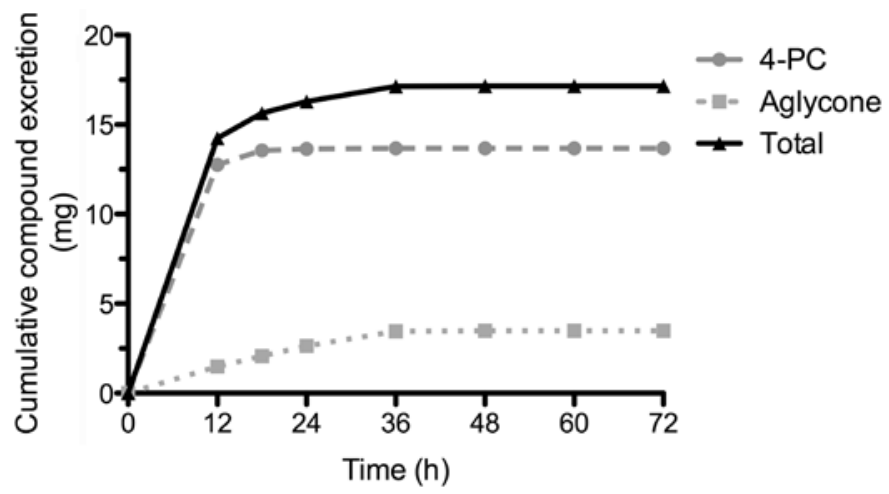

Fig. 3. Preliminary pharmacokinetic study in rats $(\mathrm{n}=6)$ after $72 \mathrm{~h}$ of a $90 \mathrm{mg} / \mathrm{kg}$ orally dose of 4-PC. A. Total cumulative excretion as percentage of dose of 4-PC and aglycone. B. Hourly cumulative compound excretion in rat feces.

instrumentation (Table 1). Additionally, the analytical method proposed had a 10 minutes total analysis time, being the shortest of all method reported for 4-phenylcoumarins studies, and is the first method with the capability of quantify simultaneously a 4-phenylcoumarin and the product of their metabolism: the aglycone. The validation parameters were within the acceptance criteria established at the NOM-177-SSA1-2013 [31] and the method extraction was highly efficient $\geq 90 \%$ for both analytes. In addition, we determined that up-to $88 \%$ of the bioactive 4-PC is eliminated in feces as the inalterable analyte and its metabolite. This is the first report of the in vivo hydrolysis of a 4-phenylcoumarin, reinforcing the in vitro and in silico evidences of the aglycone bioactivity, mainly as an $\alpha$-glucosidases inhibitor [8]. Consequently, the current method could be used to determine pharmacokinetic variables in further preclinical and clinical studies of copalchi extracts, as well as for the evaluation of quality control parameters in copalchi preparations frequently used in herbolaria for the treatment of gastritis and type 2 diabetes.

\section{Acknowledgments}

This paper was taken in part from the $\mathrm{PhD}$ thesis of S. Cristians, Graduate Program in Biological Sciences of the National Autonomous University of Mexico (UNAM). This work was supported by grants: DGAPA-UNAM (IN218110), PAPIIT IT200912, Consejo Nacional de Ciencia y Tecnología (CONACYT-Salud) 150966. We would like to thank, Dr. Rachel Mata, who has provided us the 4-PC and its aglycone standards, MVZ. Héctor Rico-Morales and MVZ. Lucía Macías-Rosales for their support in the management of animals and Q. Laurel Élide Fabila Ibarra for their technical support in lyophilization. S. Cristians acknowledges the scholarship provided by the National Council of Science and Technology (CONACyT) to pursue graduate studies.

\section{Compliance with ethical standards}

Conflict of interest The authors declare that they have no conflict of interest.

\section{References}

1. Mociño, J.M. An. Hist. Nac. 1802, 3, 288-296.

2. Gentry, H.S. Rio Mayo plants: a study of the flora and vegetation of the Valley of the Rio Mayo, Sonora. Washington, Carnegie Institution of Washington, 1942.

3. Díaz, J.L. Usos de las plantas medicinales de México: monografias científicas I y II. México, Instituto Mexicano para el Estudio de las Plantas Medicinales, 1976.

4. Bye, R. Econ. Bot. 1986, 40, 103-124.

5. Sahagún, B. Historia general de las cosas de Nueva España: primera versión íntegra del texto castellano del manuscrito conocido como Códice Florentino (1540-1585). Madrid, Editorial Alianza, 1988.

6. Martínez, M. Las Plantas Medicinales de México. México, Editorial Botas, 1989.

7. Argueta, A.V.; Cano, L.M.; Rodarte, M.E. Atlas de las Plantas Medicinales de México. México, Instituto Nacional Indigenista, 1994.

8. Mata, R.; Cristians, S.; Escandón-Rivera, S.; Juárez-Reyes, K.; Rivero-Cruz, I. J. Nat. Prod. 2013; 76, 468-483.

9. Cristians, S.; Bye, R.; Navarrete, A; Mata, R. J. Ethnopharmacol. 2013, 145, 530-535.

10. Reher, G.; Kraus, L. J. Nat. Prod. 1984, 47, 172-174.

11. Reguero, M.T.; Mata, R.; Bye, R.; Linares, E.; Delgado, G. J. Nat. Prod. 1987, 50, 315-316.

12. Mata, R.; Camacho, MR.; Cervera, E, Bye R, Linares E. Phytochemistry. 1990, 29, 2037-2040.

13. Mata, R.; Camacho, M. Del Rayo; Mendoza, S.; Cruz, M. Del Carmen. Phytochemistry. 1992, 31, 3199-31201.

14. Argotte-Ramos, R.; Ramírez-Ávila, G.; Rodríguez-Gutiérrez, M.C.; Ovilla-Muñoz, M.; Lanz-Mendoza, H.; Rodríguez, M.; 
González-Cortázar, M.; Alvarez, L. J. Nat. Prod. 2006, 69, 1442-1444.

15. Landa, E. An. Ins. Med. Nac. 1913, 12, 146-158.

16. Terres, J. An. Ins. Med. Nac. 1913, 12, 104-129.

17. Guerrero-Analco, A.; Medina-Campos, O.; Brindis, F.; Bye, R.; Pedraza-Chaverri, J.; Navarrete, A.; Mata, R. Phytochemistry. 2007, 68, 2087-2095.

18. Paris, R.R.; Bastien, M. Ann. Pharm. Franc. 1960, 18, 205-219.

19. Pinto, A.; Capasso, A.; Sorrentino, L. Drug. Res. 1997, 47, 829-833.

20. Korec, R.; Heinz-Sensch, K.; Zoukas, T. Drug. Res. 2000, 50, $122-128$.

21. Korecova, M.; Hladicova, M.; Korec, R. Z. Phytother. 2006, 27, 272-278.

22. Noster, S.; Kraus, L. Planta. Med. 1990, 56, 63-65.

23. Rojas, A.; Hernández, L.; Pereda-Miranda, R.; Mata, R. J. Ethnopharmacol. 1992, 35, 275-283.

24. Guerrero-Analco, J.A.; Hersch-Martínez, P.; Pedraza-Chaverri, A.; Navarrete, A.; Mata, R. Planta Med. 2005, 71, 1099-1105.

25. Déciga-Campos, M.; Rivero-Cruz, I.; Arriaga-Alba, M.; Castañeda-Corral, G.; Ángeles-López, G.E.; Navarrete, A.; Mata, R. J. Ethnopharmacol. 2007, 110, 334-342.

26. Hernández-Ávila, M.; Gutierrez, J.P.; Encuesta Nacional de Salud y Nutrición. Evidencia para la política pública en salud. Diabetes Mellitus: La urgencia de reforzar la respuesta en políticas públicas para su prevención y control. México. Instituto Nacional de Salud Pública; 2012.
27. Mata, R.; Acevedo, L.; Méndez-Bautista, D.I.; Guerrero-Analco, J.A.; Rivero, B.E.; Rodríguez, J.M. Pharm. Biol. 2008, 46, $105-116$

28. Cristians, S.; Guerrero-Analco, J.A.; Pérez-Vásquez, A.; Palacios-Espinosa, F.; Ciangherotti, C.; Bye, R.; Mata, R. J. Nat. Prod. 2009, 72, 408-413.

29. Pérez-Vásquez, A.; Castillejos-Ramírez, E.; Cristians, S.; Mata, R. J. Nat. Prod. 2014, 77, 516-520.

30. US Food Administration. Guidance for Industry: Bionalytical Method Validation. US Department of Health and Human Services, Food and Drug Administration, Center for Drug Evaluation and Research: Rockville, MD, 2001. Available from: http://www. $\mathrm{fda} /$ gov/dowlands/Drug/GuidanceComplianceRegulatoryInformation/Guidances/UCM070107.pdf

31. Secretaría de Salud. Norma Oficial Mexicana: NOM-177SSA1-2013. Diario Oficial de la Federación, September 20 ${ }^{\text {th }}, 2013$.

32. Viswanathan, C.T.; Bansal, S.; Booth, B.; De Stefano, A.J.; Rose, M.J.; Sailstad, J.; Shah, V.P.; Skelly, J.P.; Seann, P.G.; Weiner, R. Pharm. Res. 2007, 24, 1962-1973.

33. ICH. 2005. Harmonized tripartite guideline. Validation of analytical procedures: text and methodology Q2 (R1). Available at: $<$ http://www.ich.org/fileadmin/Public_Web_Site/ICH_Products/ Guidelines/Quality/Q2_R1/Step4/Q2_R1_Guide_line.pdf > 